\title{
Assessment of needle tip geometry during infusions into a brain phantom gel
}

\author{
Evaluación de la geometría de la punta de la aguja durante infusiones en gel de \\ agarosa
}

\author{
G. A. Orozco-Grajales ; ; G. F. Casanova-García iD , J. J. García-Álvarez iD \\ DOI: https://doi.org/10.22517/23447214.21511 \\ Artículo de investigación científica y tecnológica
}

\begin{abstract}
Convection-enhanced delivery (CED) is a promising method to deliver therapeutic drugs directly into the brain that has shown limited efficacy, mainly attributed to backflow, in which the infused drug flows back along the needle track rather than forward into tissue. This study evaluates the effect of sharp and blunt needle tips on backflow length under different flow rates via CED. Infusions were performed in a transparent $0.6 \%$ (w/v) brain phantom agarose hydrogel. Backflow length was significantly higher using sharp-tip needles for higher flow rates. No significant differences were observed between tip shapes for lower flow rates. In conclusion, sharp-tip needles present limitations for higher flow rates, which are needed to deliver more drug during shortest times.
\end{abstract}

Index Terms - backflow, brain phantom gel, convectionenhanced delivery, drug infusion, needle insertion.

Resumen - Convection-enhanced delivery es una técnica para suministrar drogas directamente en el cerebro para el tratamiento de enfermedades del sistema nervioso central. Este método ha mostrado una limitada eficacia atribuida principalmente al fenómeno de backflow, en el cual, la sustancia fluye hacia atrás por fuera de la aguja en vez de alcanzar la región del tejido delante de la punta. Este estudio evalúa el efecto de los tipos de punta plana y biselada sobre el fenómeno de backflow bajo diferentes caudales. Las infusiones experimentales se realizaron en gel de agarosa transparente al $0.6 \%(w / v)$. La longitud de backflow fue significativamente mayor para infusiones con aguja biselada a caudales mayores. No se observaron diferencias significativas entre ambos tipos de aguja para caudales menores. En conclusión, agujas con punta biselada

This manuscript was sent on April 26, 2018 and accepted on September 23, 2020.

This work was supported by the Colciencias program 516-2012 "Programa Nacional de Ciencia y Tecnología de la Salud" No. 110656933826. Thanks for the European Union's Horizon 2020 research and innovation programme under the Marie Skłodowska-Curie No 713645.

G. A. Orozco is a researcher at Department of Applied Physics of the University of Eastern Finland, Kuopio, Finland. (correspondence author)

(gustavo.orozco@uef.fi)

F. Casanova is a professor at School of Mechanical Engineering of the Universidad del Valle, Cali, Colombia.

(gonzalo.casanova@correounivalle.edu.co)

J.J. García-Álvarez is a professor at School of Civil and Geomatics Engineering of the Universidad del Valle, Cali, Colombia.

(jose.garcia@correounivalle.edu.co) presentan limitaciones a mayores caudales, las cuales son requeridas para suministrar mayor cantidad de fármaco durante los procedimientos clínicos.

Palabras claves - Backflow, entrega mejorada por convección, gel de agarosa, infusión de drogas, inserción de aguja.

\section{INTRODUCTION}

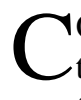
ONVECTION-ENHANCED delivery (CED) is a novel technique to bypass the blood-brain barrier and deliver therapeutic drugs over localized zones in the brain for the treatment of disorders and tumors [1]-[4]. This promising method generates a positive pressure at the tip of an infusion catheter to distribute molecules directly through the interstitial spaces of the brain tissue. Although several CED experimental studies have reported promising results[5]-[8], some clinical trials[9]-[12] have been largely unsuccessful due to poor drug distribution in target areas, mainly related with an undesirable effect of backflow, where the infused drug preferentially flows thorough an annular zone around the needle, toward the surface of the brain rather than through of the tissue target [13]. Agarose gel has been reported as a suitable brain phantom to perform infusion experiments to evaluate the effect of infusion rate, insertion velocity, and needle size on the backflow length. These experiments are useful to propose improvements for clinical application of CED [14], [15].

Panse et al. [16] reported experiments in a brain phantom gel using needles of different diameters and configurations aimed at reducing the backflow length. This study evaluated the importance of air bubbles on backflow. However, the potential effects of catheter shape on fluid distributions was not considered. Casanova et al. [17] evaluated the influence of needle insertion velocity on backflow on the agarose gel. These experiments showed that faster insertions reduce the backflow length and damage. Nevertheless, one single tip shape was utilized during those experiments.

Conventionally, needles with a blunt tip are used during insertions and infusions since the tissue reveals smaller damage compared to that produced with other needle tip 
shapes [18], [19]. For instance, needles with a beveled tip might increase the risk of damaging or infection during the insertion into the brain. However, recent strategies include designing new shape tips as well as multiport catheters [20], [21] to overcome the limitations of drug distribution in the brain.

Recently, an innovative sharp-tip needle that may reduce backflow by generating smaller local damage during insertion has been developed. Hence, the objective of this study was to evaluate whether a needle with a sharp tip reduces the backflow length during infusion into the agarose gel. We performed in vitro infusion experiments to measure the backflow lengths under combinations of two needle-tip shapes (blunt and sharp) and flow rates. From those experiments, we report the obtained distributions and the backflow lengths for each studied needle. The conducted investigation is relevant for the optimization of tip designs, and the new development of needles for CED applications.

\section{METHODS}

\section{A. Infusions experiments in agarose gel}

Needle insertions and infusions experiments were performed in samples of $0.6 \%(\mathrm{w} / \mathrm{v})$ agarose hydrogel (TreviGel 5000, Trevigen Inc., Gaithersburg, MD) cast into $100 \mathrm{ml}$ Pyrex ${ }^{\circledR}$ beakers (internal diameter $45 \mathrm{~mm}$, height 70 $\mathrm{mm})$. The dye infused into the gel was Evans blue albumin (1:2 molar ratio). The infusion system consisted of a syringe pump driving a $100 \mu$ l gas-tight syringe (Hamilton, Reno, NV) coupled to $400 \mathrm{~mm}$ of minimally compliant tubing (inner diameter $1 \mathrm{~mm}$, outer diameter $1.58 \mathrm{~mm}$ ) that was connected to the needle (Fig. 1). Two different needles were used: blunt and sharp tip with $0.36 \mathrm{~mm}$ outside diameter $(50.8 \mathrm{~mm}$ length, Hamilton, Reno, NV) (Fig. 2). The needle was carefully driven by hand with a micrometer attached to a stereotaxic frame (Kopf, Tujunga, CA) to a $20 \mathrm{~mm}$ depth at $1.2 \mathrm{~mm} / \mathrm{s}$. Infusion started immediately after insertion. In all combinations, the infusion volume was $5.0 \mu \mathrm{l}$ at a flow rate of $0.3,0.5,1$, and $2 \mu 1 / \mathrm{min}$.

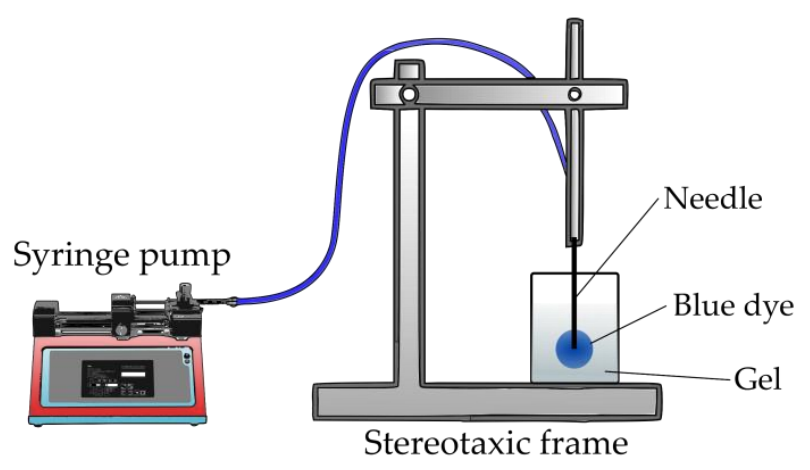

Fig. 1. Schematic of experimental setup for needles testing by CED infusion experiments into agarose gel.
The experiments were repeated ten times for each combination, with 80 measurements in total. Following the infusion, backflow was measured as the length from the needle tip to the point of maximum dye penetration back along the needle track. The measurement was accomplished using the micrometer of the stereotactic frame. In the cases when backflow reached the external surface of the gel, the backflow length was taken to be $20 \mathrm{~mm}$.

\section{B. Statistical analysis}

Two-way analysis of variance (ANOVA) was conducted to test whether the means of groups were equal. Means of backflow lengths were compared for the two needle tips (blunt and sharp) and the four flow rates $(0.3,0.5,1$, and $2 \mu 1 / \mathrm{min})$ by using the Tukey's test. Data is shown as mean \pm 1 standard deviation and $p$-values $<0.05$ were considered significant.
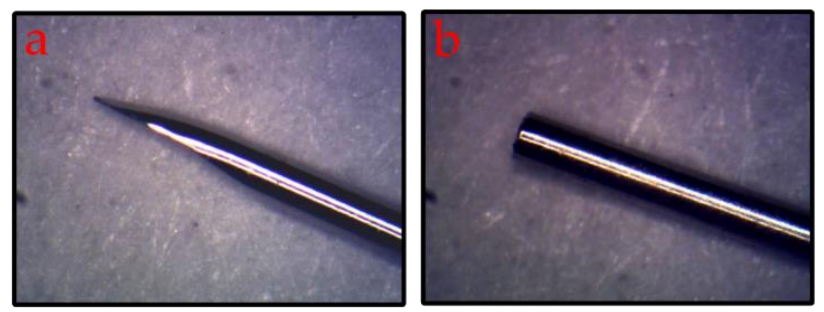

Fig. 2. Needle tips evaluated in the infusion experiments into agarose gel (outside diameter: $0.36 \mathrm{~mm}$ ). (a) Sharp and (b) blunt tip.

\section{RESULTS}

\section{A. Backflow length during infusions}

Representative dye distributions were spherical and symmetrical for lower flow rates $(0.3$ and $0.5 \mu \mathrm{l} / \mathrm{min})$ and both needle tips. In contrast, infusions with higher flow rates (1 and $2 \mu \mathrm{l} / \mathrm{min}$ ) showed irregular dye spreads for both type of needles (Fig. 3).

The ANOVA revealed significant main effects and interaction effects. Backflow length was significantly smaller for the $0.3 \mu \mathrm{l} / \mathrm{min}$ flow rate compared to those for the other three flows (p-values $=0.01,0.00$, and 0.00 for $0.5,1$, and 2 $\mu 1 /$ min, respectively.) The average backflow length was $9.7 \pm 5.44$, and $13.9 \pm 6.66 \mathrm{~mm}$ for the blunt and sharp tip, respectively. For the flow rates $0.3,0.5,1$, and $2 \mu \mathrm{l} / \mathrm{min}$ the average backflow length was $5.2 \pm 2.3,11.9 \pm 5.5,14.0 \pm 5.5$, and $16.0 \pm 5.6 \mathrm{~mm}$, respectively.

Simple main effects analysis showed that for the sharp tip needles, the backflow length was significantly greater for higher flow rates, while for the blunt tip needles, only the backflow length for $0.3 \mu \mathrm{l} / \mathrm{min}$ was significantly smaller than that for the $2 \mu 1 / \mathrm{min}$ flow rate. (p-value $=0.021$ ). For the 1 $\mu \mathrm{l} / \mathrm{min}$ and $2 \mu \mathrm{l} / \mathrm{min}$ flow rates, the backflow length was 
significantly higher for sharp tip needles than that for blunt tip and no significant differences with respect to needle tip type were found at the 0.3 and $0.5 \mu \mathrm{l} / \mathrm{min}$ flow rate (Fig. 4).
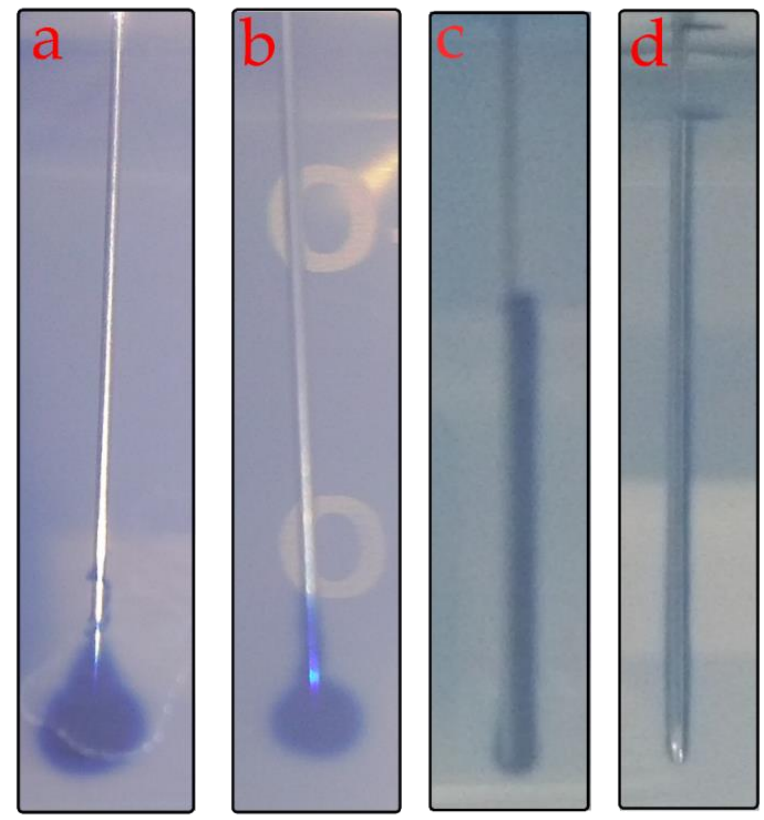

Fig. 3. Typical dye distributions in agarose gel for each needle tip: (a) blunt tip with low flow rate, (b) sharp tip with low flow rate, (c) blunt tip with high flow rate, (d) sharp tip with high flow rate.

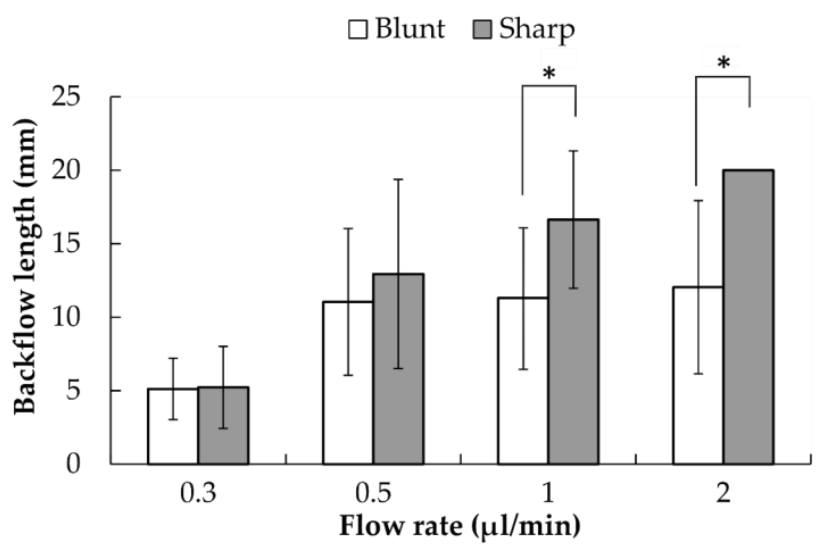

Fig. 4. Average backflow length for each needle tip type at different flow rates with $n=10$ (* indicates $p$-value $<0.05)$.

\section{DISCUSSION}

In the present study, we performed infusions in agarose gel with two needle tip types and four different flow rates to determine the effect of each tip on the backflow length. The dye distributions and the backflow lengths were similar for both tips at lower flow rates. The greater backflow produced during the infusions with sharp tip needle might be related to the lack of symmetry of the needle and the local damage generated during the insertion. In this process with sharp tip needle, the agarose gel is mainly compressed on one side and might produce a wider gap between the external surface of the needle and the phantom tissue.

Similar results with both needles were obtained for low flow rate values, however, as the flow rate was increased, backflow was greater for sharp tip needle. In contrast, the increase of flow rate using blunt tip needle did not significantly affect the backflow lengths. This is a relevant result for future clinical applications, since higher flow rates provide high amount of therapeutic and reduce the operation time.

The mechanical response of phantom material during the insertion for each needle tip might explain the differences on fluid distributions. The axial force in the sharp tip could have been higher during penetration into the agarose gel than the blunt tip. Gerwenet al. [18] reported variations in the axial forces for different needle tip shapes during insertion into distinct materials. Based on this, a blunt needle cuts more easily than a sharp one, hence sharp needles tend to create more damage in the material during the insertion. Shergold et al. [22] reported different behavior of the axial force with sharp needle in comparison with blunt needle. In those experiments, they documented that the sharp tipped needle penetrates by the formation and opening of a planar crack, while a blunt needle penetrates by the propagation of a ring crack and subsequent higher deformation of the tissue. These findings might explain why often backflow appears during the infusion with the sharp needle contrasted with the blunt needle, where the fluid is restricted by the radial compressive deformation after insertion.

In conclusion, our results suggest that sharp tip needle is not a suitable catheter for insertions and CED infusions into brain phantom gel for higher flow rates. However, future infusions in animal brain tissue should be carried to determine whether this tip might be appropriate for CED in brain tissue.

\section{ACKNOWLEDGMENTS}

This study has received funding from Colciencias program 569-2012 Grant No 110656933826 "Programa Nacional de Ciencia y Tecnología de la Salud". Thanks for the European Union's Horizon 2020 research and innovation programme under the Marie Skłodowska-Curie No 713645.

\section{REFERENCES}

[1] R. H. Bobo, D. W. Laske, A. Akbasak, P. F. Morrison, R. L. Dedrick, and E. H. Oldfield, "Convection-enhanced delivery of macromolecules in the brain," Proc. Natl. Acad. Sci., vol. 91, no. 6, pp. 2076-2080, Mar. 1994. DOI:10.1073/pnas.91.6.2076

[2] P. F. Morrison, D. W. Laske, H. Bobo, E. H. Oldfield, and R. L. Dedrick, "High-flow microinfusion: tissue penetration and 
pharmacodynamics," Am. J. Physiol. - Regul. Integr. Comp. Physiol., vol. 266, no. 1, pp. R292-R305, Jan. 1994.

DOI:10.1152/ajpregu.1994.266.1.R292

[3] M. A. Vogelbaum and M. K. Aghi, "Convection-enhanced delivery for the treatment of glioblastoma," Neuro-Oncol., vol. 17 Suppl 2, pp. ii3-ii8, Mar. 2015. DOI:10.1093/neuonc/nou354

[4] A. M. Mehta, A. M. Sonabend, and J. N. Bruce, "ConvectionEnhanced Delivery," Neurotherapeutics, vol. 14, no. 2, pp. 358-371, Apr. 2017. DOI:10.1007/s13311-017-0520-4

[5] M. L. Brady et al., "In vivo performance of a microfabricated catheter for intraparenchymal delivery," J. Neurosci. Methods, vol. 229, pp. 76-83, May 2014. DOI: 10.1016/j.jneumeth.2014.03.016

[6] M. T. Krauze, J. Forsayeth, J. W. Park, and K. S. Bankiewicz, "Realtime Imaging and Quantification of Brain Delivery of Liposomes," Pharm. Res., vol. 23, no. 11, pp. 2493-2504, Nov. 2006. DOI: 10.1007/s11095-006-9103-5

[7] K. H. Rosenbluth, A. J. Martin, J. Bringas, and K. S. Bankiewicz, "Evaluation of pressure-driven brain infusions in nonhuman primates by intra-operative 7 Tesla MRI," J. Magn. Reson. Imaging JMRI, vol. 36, no. 6, pp. 1339-1346, Dec. 2012. DOI:10.1002/jmri.23771

[8] E. White et al., "An evaluation of the safety and feasibility of convection-enhanced delivery of carboplatin into the white matter as a potential treatment for high-grade glioma," J. Neurooncol., vol. 108, no. 1, pp. 77-88, May 2012. DOI:10.1007/s11060-012-0833-4

[9] J. H. Sampson et al., "Poor drug distribution as a possible explanation for the results of the PRECISE trial," J. Neurosurg., vol. 113, no. 2, pp. 301-309, Aug. 2010. DOI:10.3171/2009.11.JNS091052

[10] S. Kunwar et al., "Phase III randomized trial of CED of IL13PE38QQR vs Gliadel wafers for recurrent glioblastoma," NeuroOncol., vol. 12, no. 8, pp. 871-881, Aug. 2010. DOI:10.1093/neuonc/nop054

[11] O. Lewis et al., "Chronic, intermittent convection-enhanced delivery devices," J. Neurosci. Methods, vol. 259, pp. 47-56, Feb. 2016. DOI:10.1016/j.jneumeth.2015.11.008

[12] M. L. Brady et al., "The relation between catheter occlusion and backflow during intraparenchymal cerebral infusions," Stereotact. Funct. Neurosurg., vol. 93, no. 2, pp. 102-109, Feb. 2015. DOI: $10.1159 / 000367665$

[13] Michael Y. Chen, Russell R. Lonser, Paul F. Morrison, Lance S. Governale, and Edward H. Oldfield, "Variables affecting convectionenhanced delivery to the striatum: a systematic examination of rate of infusion, cannula size, infusate concentration, and tissue - cannula sealing time," May 2009. DOI:10.3171/jns.1999.90.2.0315,

[14] L. C. Vazquez et al., "Polymer-coated cannulas for the reduction of backflow during intraparenchymal infusions," J. Mater. Sci. Mater. Med., vol. 23, no. 8, pp. 2037-2046, Aug. 2012. DOI:10.1007/s10856$012-4652-0$

[15] O. Ivanchenko, N. Sindhwani, and A. Linninger, "Experimental techniques for studying poroelasticity in brain phantom gels under high flow microinfusion," J. Biomech. Eng., vol. 132, no. 5, p. 051008, May 2010. DOI:10.1115/1.4001164

[16] S. J. Panse, H. L. Fillmore, Z. J. Chen, G. T. Gillies, and W. C. Broaddus, "A novel coaxial tube catheter for central nervous system infusions: performance characteristics in brain phantom gel," J. Med. Eng. Technol., vol. 34, no. 7-8, pp. 408-414, Oct. 2010. DOI:10.3109/03091902.2010.508556

[17] F. Casanova, P. R. Carney, and M. Sarntinoranont, "Influence of Needle Insertion Speed on Backflow for Convection-Enhanced Delivery," J. Biomech. Eng., vol. 134, no. 4. DOI:10.1115/1.4006404
[18] D. J. van Gerwen, J. Dankelman, and J. J. van den Dobbelsteen, "Needle-tissue interaction forces - A survey of experimental data," Med. Eng. Phys., vol. 34, no. 6, pp. 665-680, Jul. 2012. DOI: 10.1016/j.medengphy.2012.04.007

[19] N. J. van de Berg, T. L. de Jong, D. J. van Gerwen, J. Dankelman, and J. J. van den Dobbelsteen, "The influence of tip shape on bending force during needle insertion," Sci. Rep., vol. 7, p. 40477, Jan. 2017. DOI:10.1038/srep40477

[20] M. A. Vogelbaum et al., "First-in-human evaluation of the Cleveland Multiport Catheter for convection-enhanced delivery of topotecan in recurrent high-grade glioma: results of pilot trial 1," J. Neurosurg., pp. 1-10, Apr. 2018. DOI: 10.3171/2017.10.JNS171845

[21] R. Raghavan and R. M. Odland, "Theory of porous catheters and their applications in intraparenchymal infusions," Biomed. Phys. Eng. Express, vol. 3, no. 2, 2017. DOI:10.1088/2057-1976/aa5a77

[22] O. A. Shergold and N. A. Fleck, "Experimental investigation into the deep penetration of soft solids by sharp and blunt punches, with application to the piercing of skin," Trans.-Am. Soc. Mech. Eng. J. Biomech. Eng., vol. 127, no. 5, p. 838, 2005. DOI:10.1115/1.1992528

Gustavo Alejandro Orozco Grajales was born in Cali, Colombia in 1989. He received the B.S. degree in Mechanical Engineering in 2011 and the M.S degree in Mechanical Engineering in 2015 from Universidad del Valle, Cali, Colombia. Then, in 2020 he received the $\mathrm{Ph} . \mathrm{D}$ degree in Medical Physics from the University of Eastern Finland, Kuopio, Finland. His research interest includes computational biomechanics of soft tissues, and mechanical characterization of biological materials.

ORCID: https://orcid.org/0000-0002-1054-7937

Gonzalo Fernando Casanova García was born in Pupiales, Colombia in 1971. He received the B.S. degree in Mechanical Engineering in 2003 and the M.S degree in Mechanical Engineering in 2006 from Universidad del Valle, Cali, Colombia. Then, in 2013 he received the Ph.D degree in Mechanical Engineering from University of Florida, Gainesville, Florida, USA. From 2007 he has been professor at Universidad del Valle, Cali, Colombia. His research interest includes biomechanics of soft tissues, fatigue and failure of mechanical components, composite materials.

ORCID: https://orcid.org/0000-0002-3146-2027

José Jaime Garcia Alvarez was born in Cali, Colombia in 1954. He received the B.S. in Mechanical Engineering from the Universidad del Valle, Cali, Colombia. Next, he received the M.Sc. and Ph.D.in Mechanics from Michigan State University in 1998. From 1980 to 1998, he was a Lecturer and Assistant Professor at the 
Universidad del Valle. From 1999 he has been Professor at the Universidad del Valle, Cali, Colombia. He is coauthor of about 50 articles and one invention. His research interests include biomechanics of soft tissues, the development of bone fixation systems, and the mechanical characterization and applications of bamboo. ORCID: https://orcid.org/0000-0003-2580-805X 